\title{
Daya Saing Perdagangan Daerah di Kabupaten Jember (Perspektif Kebijakan Publik)
}

\author{
Herman Cahyo Diartho ${ }^{{ }^{*}}$ \\ ${ }^{1}$ Program Studi Ekonomi Pembangunan, Fakultas Ekonomi dan Bisnis, Universitas Jember \\ Jln. Kalimantan 37, Jember 68121 Indonesia \\ *e-mail: hermancahyodiartho@yahoo.com
}

\begin{tabular}{cl}
\hline & ABSTRAK \\
\cline { 2 - 3 } Artikel Info & Hasil penelitian yang dilakukan mempunyai tujuan \\
Received : & menganalisis jenis komoditas yang berdaya saing paling \\
27Januari 2020 & tinggi dan kebijakan yang mendorong peningkatan daya saing \\
Revised : & subsektor tanaman perkebunan di Jember. Alat analisis yang \\
16 Maret 2020 & digunakan untuk menganalisis kebijakan peningkatan daya \\
Accepted : & saing, yaitu Revealed Comparative Advantaged (RCA) dan \\
12 Juni 2020 & Analytical Hierarky Process (AHP). Alat analisis RCA \\
& menghasilkan bahwa tanaman perkebunan dengan komoditas \\
& tembakau mempunyai nilai daya saing paling kuat sebesar \\
& 5,45. Hasil penelitian ini menunjukkan bahwa kebijakan kerja \\
& sama antar daerah sebagai kebijakan yang memiliki bobot \\
& tertinggi sebesar 0,82.
\end{tabular}

Kata Kunci : Perdagangan, Daya Saing, Subsektor.

\section{Regional Trade Competitiveness In Jember Regency (Public Policy Perspective)}

\section{ABSTRACT}

This research aims to know the policies that help in increasing the competitiveness of the subsector crops plantations in Kabupaten Jember. Analysis tools are used to find out the strategy of increasing competitiveness in the study was Analytical Hierarky Process (AHP). RCA analysis tools produce that plantation crops with tobacco commodities have the strongest competitiveness value of 5.45. The results of this research show that cooperation between regional policy as a policy that has the highest weight of 0.82 .

Keywords : Trade, Competitiveness, Subsector.

\section{PENDAHULUAN}

Pertumbuhan ekonomi suatu daerah membantu dalam pembangunan ekonomi dikarenakan semakin tinggi pertumbuhan ekonomi suatu daerah akan memperlancar proses pembangunan ekonomi. Pembangunan ekonomi daerah dapat dibantu dengan wewenang 
otonomi daerah untuk membantu menemukan potensi dari struktur atau sektor ekonomi daerah. Otonomi daerah merupakan wewenang untuk mengelola segala kepentingan masyarakat dengan mengacu pada kepentingan publik dengan berdasarkan pada perundang-undangan yang berlaku (Widjaja, 2011). Sektor potensial suatu daerah memiliki subsektor yang juga berkontribusi bagi pertumbuhan ekonomi. Subsektor potensial tersebut dapat ditingkatkan daya saingnya untuk dapat dialokasikan dalam ekonomi perdagangan antar daerah yang dapat dikelola dengan dengan intervensi pemerintah. Salah satu bentuk pengelolaan pada perdagangan antar daerah adalah formulasi kebijkan publik. Hasil penelitian ini menggunakan tiga bentuk kebijakan publik yaitu kebijakan kerja sama antar daerah, penguatan fiskal dan moneter serta pelayanan publik.

Pemilihan Kabupaten Jember dikarenakan Kabupaten Jember memiliki lahan pertanian yang luas, yang dapat dilihat pada tabel 1 .

Tabel 1. Luas Sumberdaya Lahan Sektor Pertanian dan

Kapasitas Pengairan Tahun 2016 (Hektar)

\begin{tabular}{|c|c|c|c|}
\hline Kabupaten & Irigasi & Non Irigasi & Jumlah \\
\hline 01. Kabupaten Pacitan & 8565 & 4218 & 12783 \\
\hline 02. Kabupaten Ponorogo & 32775 & 2026 & 34801 \\
\hline 03. Kabupaten Trenggalek & 11626 & 1255 & 12881 \\
\hline 04. Kabupaten Tulungagung & 24975 & 2641 & 27616 \\
\hline 05. Kabupaten Blitar & 28657 & 3023 & 31680 \\
\hline 06. Kabupaten Kediri & 46510 & 814 & 47324 \\
\hline 07. Kabupaten Malang & 42739 & 3149 & 45888 \\
\hline 08. Kabupaten Lumajang & 33547 & 3206 & 36753 \\
\hline 09. Kabupaten Jember & 84964 & 1180 & 86144 \\
\hline 10. Kabupaten Banyuwangi & 64105 & 1154 & 65259 \\
\hline 11. Kabupaten Bondowoso & 35451 & 258 & 35709 \\
\hline 12. Kabupaten Situbondo & 31836 & 2226 & 34062 \\
\hline 13. Kabupaten Probolinggo & 34710 & 2545 & 37255 \\
\hline 14. Kabupaten Pasuruan & 37647 & 2158 & 39805 \\
\hline 15. Kabupaten Sidoarjo & 21852 & 219 & 22071 \\
\hline 16. Kabupaten Mojokerto & 31045 & 5571 & 36616 \\
\hline 17. Kabupaten Jombang & 42014 & 6693 & 48707 \\
\hline 18. Kabupaten Nganjuk & 38252 & 4666 & 42918 \\
\hline 19. Kabupaten Madiun & 31163 & 1883 & 33046 \\
\hline 20. Kabupaten Magetan & 27190 & 1060 & 28250 \\
\hline 21. Kabupaten Ngawi & 46212 & 3985 & 50197 \\
\hline 22. Kabupaten Bojonegoro & 38146 & 40371 & 78517 \\
\hline 23. Kabupaten Tuban & 29337 & 27054 & 56391 \\
\hline 24. KabupatenLamongan & 53243 & 34590 & 87833 \\
\hline 25. Kabupaten Gresik & 7992 & 30061 & 38053 \\
\hline 26. Kabupaten Bangkalan & 8049 & 21491 & 29540 \\
\hline 27. Kabupaten Sampang & 4757 & 15830 & 20587 \\
\hline 28. Kabupaten Pamekasan & 7325 & 10581 & 17906 \\
\hline 29. Kabupaten Sumenep & 8819 & 16747 & 25566 \\
\hline
\end{tabular}

Sumber : Disperta Tanaman Pangan Jawa Timur, 2016. 


\section{EKONOMIKAWAN : Jurnal Ilmu Ekonomi dan Studi Pembangunan}

I55N : $1693-7600$ (Print), 155N : 2598-0157 (Online), hutp://fumal_umstiac.id//index.php/ekawan

Kabupaten Jember juga memiliki luas lahan perkebunan kedua terluas di Jawa Timur setelah Pamekasan. Kabupaten Jember jika dibandingkan dengan Kabupaten Lumajang jauh memiliki lahan perkebunan yang lebih luas. Jumlah ekspor yang berasal dari wilayah Kabupaten Jember juga lebih dominan terutama pada komoditi tembakau sebagai hasil dari subsektor tanaman perkebunan. Kabupaten Jember merupakan daerah yang memiliki jumlah produksi terbanyak kedua di Jawa Timur.

Tabel 2. Luas Tanaman Perkebunan Jawa Timur Tahun 2016

\begin{tabular}{|c|c|c|c|c|c|c|c|}
\hline Kabupaten & Karet & Kelapa & Cengkeh & Kopi & Tebu & Kakao & Lainnya \\
\hline Kabupaten Pacitan & - & 24725 & 8163 & 2192 & - & 6007 & 3129 \\
\hline Kabupaten Ponorogo & - & 4907 & 2802 & 1048 & 1017 & 2322 & 5393 \\
\hline Kabupaten Trenggalek & - & 15211 & 5708 & 566 & 336 & 4355 & 742 \\
\hline Kabupaten Tulungagung & 353 & 19733 & 1845 & 761 & 6071 & 1829 & 2602 \\
\hline Kabupaten Blitar & 1042 & 19015 & 3153 & 5847 & 6790 & 5090 & 3980 \\
\hline Kabupaten Kediri & 349 & 9276 & 2013 & 3708 & 27249 & 4270 & 22762 \\
\hline Kabupaten Malang & 203 & 13917 & 5456 & 17547 & 44318 & 3631 & 8352 \\
\hline Kabupaten Lumajang & 477 & 8132 & 2073 & 4714 & 20184 & 2778 & 11088 \\
\hline Kabupaten Jember & 10688 & 13795 & 1117 & 18230 & 9517 & 4029 & 22807 \\
\hline Kabupaten Banyuwangi & 5602 & 28112 & 2789 & 17979 & 6039 & 9538 & 13589 \\
\hline Kabupaten Bondowoso & - & 4246 & 110 & 12798 & 4341 & 95 & 5168 \\
\hline Kabupaten Situbondo & - & 4361 & 10 & 3028 & 8222 & - & 6773 \\
\hline Kabupaten Probolinggo & - & 4110 & 894 & 4857 & 3815 & 8 & 15194 \\
\hline Kabupaten Pasuruan & - & 5927 & 1315 & - & 4546 & - & 20459 \\
\hline Kabupaten Sidoarjo & - & 1746 & - & - & 4148 & - & 468 \\
\hline Kabupaten Mojokerto & - & 621 & 160 & 166 & 9233 & - & 1833 \\
\hline Kabupaten Jombang & 29 & 1270 & 2186 & 1333 & 9259 & 1690 & 4708 \\
\hline Kabupaten Nganjuk & - & 3332 & 2279 & 218 & 3201 & 2619 & 6317 \\
\hline Kabupaten Madiun & 279 & 3962 & 1761 & 1477 & 2892 & 5761 & 6848 \\
\hline Kabupaten Magetan & - & 2823 & 941 & 667 & 7543 & 995 & 9867 \\
\hline Kabupaten Ngawi & 1302 & 6162 & 814 & 1152 & 6116 & 2033 & 15540 \\
\hline Kabupaten Bojonegoro & - & 7883 & - & - & 1694 & - & 7255 \\
\hline Kabupaten Tuban & - & 5292 & - & - & 1641 & - & 5912 \\
\hline Kabupaten Lamongan & - & 1860 & - & - & 5600 & - & 14211 \\
\hline Kabupaten Gresik & - & 4635 & 46 & - & 2374 & - & 188 \\
\hline Kabupaten Bangkalan & - & 7868 & 20 & - & 617 & - & 13567 \\
\hline Kabupaten Sampang & - & 3290 & - & - & 1582 & - & 14308 \\
\hline Kabupaten Pamekasan & - & 3756 & - & 6769 & - & - & 13508 \\
\hline Kabupaten Sumenep & - & 51171 & 245 & 18 & 195 & 52 & 39718 \\
\hline
\end{tabular}

Sumber: Dinas Perkebunan Provinsi Jawa Timur, 2016.

\section{METODE}

Penelitian yang akan dilakukan ini berbasis pada data persepsi responden dengan menyebar kuesioner kepada pihak yang ekspert diantaranya, yaitu : Disperindag Kabupaten Jember, Dinas Tanaman Pangan dan Holtikultura, dan Bappeda Kabupaten Jember. 


\section{Revealed Comparative Advantage (RCA)}

Penelitian ini menggunakan pendekatan dengan menganalisis tingkat daya saing produk di pasar ekspor yang berasal dari Kabupaten jember. Alat analisis yang digunakan adalah RCA Revealed Comparative Advantagedengan formulasi sbagai berikut (Satryana dan Karmini, 2016):

$$
\mathrm{RCA}=\frac{\frac{X \mathbf{X j}}{\mathrm{Xj}}}{\frac{X i w}{X w}}
$$

Keterangan : Xij merupakan nilai ekspor komoditi $\mathrm{X}$ oleh yang berasal dari Jember. Adapun $\mathrm{Xj}$ adalah nilai keseluruhan dari ekspor Jember. Notasi Xiw adalah nilai ekspor total Jawa Timur yang merupakan komoditas X. Xw adalah nilai ekspor total Jawa Timur. Apabila indeks hasil persamaan RCA dengan nilai sama atau lebih dari satu $(\mathrm{RCA} \geq 1)$ berarti bahwa komoditas yang berasal dari Jember memiliki daya saing artinya produk diatas rata-rata provinsi Jawa Timur (kuat) dan apabila indeks RCA menunjukkan nilai kurang dari satu $(\mathrm{RCA}<1)$ maka daya saing suatu produk dari negara tersebut di bawah rata-rata dunia (lemah).

\section{Analytical Hierarchy Process (AHP)}

Alat analisis AHP merupakan instrumen penelitian yang dipergunakan untuk memformulasikan suatu keputusan yang menjadi prioritas terhadap alternatif dari rangkaian masalah yang ada. Alat analisis digunakan untuk membantu mencarikan solusi terhadap permasalahan yang kompleks. Rangkaian masalah yng kompleks tersebut disusun dengan sebuah hirarki dengan sistem perhitungan pembobotan atau prioritas. Alat analisis AHP mempunyai beberapa langkah dalam penyelesainnya, antara lain :

a. Menentukan permasalahan dan solusi.

Menyusun struktur hirarki dengan susunan sebagai berikut : tujuan, kriteria, sub kriteria dan alternatif.

b. Menyusun tabel perbandingan berpasangan dengan memperhatikan pada aspek kriteria dan subkriteria.

c. Memformulasikan bobot relatif dengan membuat tabel penilaian perbandingan berpasangan.

d. Selanjutnya dilakukan pembobotandan uji konsistensi indeks dan rasio yang dapat mengarah pada tidakkonsistenan jawaban.

$$
\mathbf{C I}=\frac{\lambda \mathbf{m a x}-\mathbf{n}}{\mathbf{n}-\mathbf{1}}
$$

Keterangan : notasi CI merupakan Consitency Index (rasio penyimpangan konsistensi). Adapun nilai $\lambda \max$ merupakan nilai eigen terbesar dari matriks berodo $\mathrm{n}$ dan $\mathrm{n}$ merupakan jumlah elemen yang dibandingkan. Selanjutnya CI mempunyai nilai nol jika terdapat standar dalam menyatakan apakah CI menunjukkan yang konsisten. Saat dalam penelitiannya menjelaskan apabila matriks yang dihasilkan dari perhitungan AHP menghasilkan nilai perbandingan secara acak merupakan matriks yang tidak konsisten. Hasil perhitungan ini akan menghasilkan nilai Consistency Index atau Random Index (RI). Tahap analisis AHP berikutnya adalah menentukan derajat konsistensi dengan pola membandingkan CI dan RI (Fahrozi, 2015).

\section{$\mathbf{C R}=\mathbf{C I} / \mathbf{R I}$}




\section{HASIL DAN PEMBAHASAN \\ Hasil Analisis RCA}

Tabel 3. Derajat Daya Saing Komoditasdari Kabupaten Jember

\begin{tabular}{cccc}
\hline No & Komoditas & RCA & Keterangan \\
\hline 1 & Tembakau & 5,45 & Daya Saing Kuat \\
\hline 2 & Coklat & 0,01 & Daya Saing Lemah \\
\hline 3 & Karet & 0,74 & Daya Saing Lemah \\
\hline
\end{tabular}

Hasil penelitian dengan menggunakan RCA menyimpulkan bahwa komoditas tembakau memiliki tingkat daya saing paling tinggi dari komoditi lain. Hasil penelitian ini didukung dengan kondisi real dari kabupaten Jember sebagai daerah kedua yang memproduksi tembakau terbanyak di provinsi Jawa Timur dengan nilai 12.722 ton pada tahun 2016. Jika dibandingkan dengan daerah pertama penghasil tembakau terbesar yaitu kabupaten Pamekasan, kabupaten Jember hanya memiliki selisih sedikit. Produksi tembakau yang banyak di kabupaten Jember juga didukung dengan luas lahan pertanian dan produktivitas dari tenaga kerja di kabupaten Jember (petani tembakau). Iklim yang mendukung juga membantu dalam produktivitas tembakau. Hasil komoditi tembakau banyak yang diperjualkan ke daerah lain karena memiliki daya saing yang tinggi dibandingkan dengan daerah lain.

Tembakau kabupaten Jember dari tahun 2010-2017 memiliki jumlah ekspor yang tinggi. Rata-rata jumlah ekspor dari tahun 2010-2017 memiliki jumlah ekspor sebesar 141.577.486,42 yang menandakan tembakau kabupaten Jember memiliki kontribusi atau penyumbang dalam pertumbuhan ekonomi daerah. Hasil empiris ini menjelaskan bahwa di kabupaten Jember sektor yang memiliki potensi adalah sektor pertanian dengan subsektor perkebunan yang memiliki nilai daya saing paling tinggi di antara subsektor lain. Lahan pertanian yang luas menjadi salah satu faktor sektor pertanian terutama komoditi tembakau menjadi penyumbang perekonomian terbesar. Lahan yang luas tersebut dapat dimanfaatkan untuk memaksimalkan pengelolaan sektor pertanian di kabupaten Jember.

\section{Hasil Analisis AHP}

Tabel 4. Hasil Analisis AHP

Priority Vector

\begin{tabular}{cc}
\hline Kerja Sama Antar Daerah & 0,829516 \\
\hline Penguatan Fis dan Mon & 0,025803 \\
\hline Pelayanan Publik & 0,13468 \\
\hline
\end{tabular}

Hasil penelitian yang telah dilakukan secara faktual terstruktur menjadi tiga alternatif kebijakan publikyang digunakan, antara lain:

a. Kesepakatan kerja sama perdagangan antar daerah

Kesepakatan untuk melakukan kerja sama perdagangan antar daerah pada konteks penelitian ini mempunyai beberapa formulasi kebijakan antara lain:

(1) Terwujudanya proses akselerasi proses efektivitas dan efisiensi terhadap pengelolaan sumber daya alam

Efektifitas dan efisiensi terhadap pengelolaan sumber daya alam akan memberikan dampak yang signifikan terhadap peningkatan daya saing sektoral perekonomian daerah serta produktivitas sumber daya alam tersebut. Produktivitas pengelolaan 


\section{EKONOMIKAWAN : Jurnal Ilmu Ekonomi dan Studi Pembangunan}

I55N : 1693 -7600 (print), $155 N$ : 2598 - 0157 (Online), http://fumalumstiac.id/index.php/ekawan

sumber daya alam akan berdampak terhadap peningkatkan kualitas dan daya saing dari sumber daya alam tersebut.

(2) Promosi potensi ekonomi daerah

Promosi potensi ekonomi daerah berdampak terhadap peningkatan daya saing sectoral. Proses peningkatan itu melalui perdagangan dengan daerah lain. Hal ini akan berdampak pada daerah lain untuk melakukan pembelian atau memberikan investasi kepada daerah yang memiliki potensi tersebut. Akumulasi peningkatan terhadap daerah lain akan memberikan pengaruh terhadap peningkatan kualitas komoditas sehingga dapat menguasai pangsa pasar domestik daerah tujuan. Oleh karena itu potensi yang dimiliki oleh suatu daerah akan berusaha menghasilkan suatu komoditas perdagangan dengan berdaya saing tinggi.

(3) Memasarkan produk berkualitas.

Aktifitas pengenalan suatu produk melalui pemasaran akan berdampak pada peningkatan daya saing sektoral perekonomian daerah. Hal dapat terjadi bahwa pemasaran suatu produk daerah lain akan memberikan benefit yang maksimal pada perdagangan antar daerah. Proses terjadinya perdagangan antar daerah akan berdampak pada daerah untuk mempromosikan produknya ke daerah lain bahkan ke pasar luar negeri.

b. Terkelolanya Pelayanan Publik

Daerah diharapkan mampu memberikan adanya suatu pelayanan publik. Pada hasil penelitian ini menggunakan beberapa perspektif pendekatan kebijakan, antara lain:

(1) Perizinan

Perizinan akan membantu dalam peningkatan daya saing sektoral karena dengan permudahan terhadap perizinan maka baik aparat pemerintah dan masyarakat akan lebih dipermudah dalam pengelolaan sumber daya alam dan produk yang akan diunggulkan oleh daerah tersebut. Perizinan juga akan menghilangkan hambatan industri-industri dalam kegiatan ekonomi sehingga selain akan meningkatkan daya saing sektoral juga akan merangsang terbentuknya hasil komoditas lain yang sebelumnya belum memiliki keunggulan.

(2) Perluasan lapangan kerja

Perluasan lapangan kerja akan membantu dalam peningkatan daya saing sektoral dikarenakan tenaga kerja yang belum bekerja akan mendapatkan pekerjaan sehingga tingkat pengangguran akan berkurang. Pengangguran yang berkurang tersebut akan membantu dalam peningkatan pertumbuhan ekonomi daerah sehingga pemasukan kas daerah meningkat dan dapat dialokasikan untuk pengelolaan sumber daya alam berpotensi tersebut. Perluasan lapangan kerja juga akan merangsang terjadinya spesialisasi produk sehingga potensi alam yang ada di suatu daerah tidak terbengkalai.

(3) Pemberian Pendidikan dan Keterampilan

Pendidikan dan keterampilan harus dilakukan oleh pemerintah daerah Kabupaten Jember dengan tujuan peningkatan daya saing sektoral ekonomi daerah. Pendidikan dan keterampilan dikhususnya bagi tenaga kerja (masyarakat) yang belum memiliki keterampilan untuk melakukan suatu pekerjaan akan dapat membantu dalam pengelolaan sumber daya alam. Pendidikan dan keterampilan akan memberikan dampak peningkatkan produktivitas dari sumber daya alam yang dikelola daerah Kabupaten Jember sehingga kompetitif dan dapat menguasai pangsa pasar. 
c. Penguatan Fiskal dan Moneter

Penguatan fiskal dan moneter dalam penelitian ini menggunakan beberapa strategi antara lain:

(1) Peningkatan investasi

Peningkatan investasi akan membantu dalam peningkatan daya saing sektoral. Hal tersebut disebabkan investasi akan mendorong banyak pihak tertarik terhadap potensi daerah sehingga modal dari investasi tersebut dapat dialokasikan untuk peningkatan produktivitas. Secara teoritis menjelaskan bahwa investasi akan memberikan dampak terhadap peningkatan daya saing dari potensi SDA sehingga dapat melakukan persaingan dalam perdagangan antar daerah.

(2) Peningkatan ekspor

Peningkatan ekspor akan membantu dalam peningkatan daya saing sektoral dikarenakan dengan adanya ekspor akan membantu daerah tersebut mengenalkan potensi daerahnya kepada daerah lain. Hal ini menjelaskan bahwa potensi atau komoditas daerah harus memiliki kualitas yang tinggi sehingga dapat bersaing dalam ekonomi perdagangan antar daerah. Kegiatan ekspor terhadap komoditas daerah juga membantu peningkatan pemasukan pendapatan daerah sehingga berkontribusi bagi pertumbuhan ekonomi daerah.

(3) Pemberian subsidi

Subsidi yang diberikan oleh pemerintah berdampak pada peningkatan daya saing komoditas daerah. Subsidi dapat berbentuk uang atau modal. Selain itu juga juga dapat berbentuk bahan baku yang berpengaruh terhadap pengelolaan sumber daya alam maupun suatu komoditas. Hal ini menjelaskan bahwa subsidi membantu peningkatan produktivitas SDA sehingga daya saing akan meningkat.

Hasil analisis penelitian dengan basis data primer dengan alat analisis metode AHP terhadap konstruksi formulasi kebijakan publik terkait perdagangan kerja sama antar daerah menghasilkan nilai dengan bobot tertinggi sebesar 0,829516. Konsep perdagangan melalui kerja sama antar daerah merupakan suatu formulasi kebijakan yang dapat meningkatan daya saing sektoral ekonomi daerah. Proses peningkatan tersebut melalui kerja sama antar daerah sehingga dalam perdagangan antar daerah akan terjadi pengelolaan sumber daya alam dilakukan secara maksimal sehingga dapat mengalahkan produk atau komoditas yang berasal dari lain.

Formulasi terhadap kebijakan publik terkait kerja sama perdagangan antar daerah menggunakan tiga strategi, yaitu: peningkatan efektifitas dan efisiensi pengelolaan sumber daya alam, promosi potensi daerah dan pemasaran produk. Ketiga strategi tersebut dapat memberikan bantuan dalam peningkatan daya saing sektoral. Peningkatan efisiensi dan efektifitas pengelolaan sumber daya alam akan berdampak pada peningkatan produktivitas sumber daya alam tersebut sehingga akan berdampak pula terhadap produktivitas dari tenaga kerja. Peningkatan produktivitas tenaga kerja akan memberikan dampak positif bagi pemaksimalan produktivitas hasil sumber daya alam yang dihasilkan. Kualitas dari hasil sumber daya alam tersebut akan meningkat sehingga sumber daya alam tersebut dikenal luas dan memiliki tingkat daya saing lebih tinggi. Daya saing yang lebih tinggi tersebut membantu dalam proses perdagangan antar daerah dikarenakan semakin tinggi tingkat daya saing sumber daya alam tersebut semakin tinggi pemasukan atau pendapatan daerah yang berdampak positif bagi pertumbuhan ekonomi Kabupaten Jember. Promosi potensi daerah juga membantu dalam peningkatan daya saing sektoral suatu daerah dikarenakan dengan adanya promosi potensi daerah terhadap daerah lain akan menunjukkan ke daerah lain bahwa daerah tersebut memiliki potensi yang dapat menunjang bagi pemerataan 
pertumbuhan ekonomi. Promosi potensi daerah yang dilakukan tersebut juga akan meningkatkan persaingan dalam perdagangan antar daerah dikarenakan semakin tinggi atau banyaknya potensi suatu daerah maka daerah lain akan terangsang untuk menemukan dan memfokuskan pada potensi daerahnya. Promosi potensi daerah juga memberikan dampak positif bagi daerah yang bersangkutan karena akan membantu dalam peningkatan ekspor daerah yang akan memberikan kontribusi bagi pertumbuhan ekonomi daerah.

Pemasaran produk merupakan salah satu strategi kerja sama antar daerah yang membantu dalam peningkatan daya saing sektoral dikarenakan dengan pemasaran produk yang kualitasnya sudah terjamin akan semakin memberikan peluang daerah yang melakukan pemasaran tersebut menarik investor asing untuk menanamkan modalnya di daerah tersebut sehingga akan membantu dalam peningkatan produktivitas dari produk daerah tersebut. Peningkatan produktivitas tersebut akan meningkatkan daya saing dan memberikan keunggulan yang lebih dari pada produk daerah lain.

\section{SIMPULAN}

1. Hasil analisis data dengan menggunakan pendekatan RCA bahwa komoditas yang memiliki tingkat daya saing tinggi adalah tembakau.

2. Hasil analisis data dengan menggunakan pendekatan AHP bahwa kebijakan yang memiliki bobot tertinggi adalah kerja sama antar daerah dengan nilai 0,82 .

\section{DAFTAR PUSTAKA}

Arsyad, Linconlin. (1999). Ekonomi Pembangunan Edisi Ke-4. Yogyakarta : Bagian Penerbitan Sekolah Tinggi Ilmu Ekonomi YKPN.

Haris, S. (2007). Desentralisasi dan Otonomi Daerah. Jakarta : Lippi Press.

Hajeri. Yurisinthae, E. Dolorosa, E. (2015). Analisis Penentuan Sektor Unggulan Perekonomian di Kabupaten Kubu Raya. Jurnal Ekonomi Bisnis dan Kewirausahaan Vol. 4, No. 2, Hal 253-269.

Jauchar B. (2012). Otonomi Daerah dan Pengelolaan Sumber Daya Alam di Propinsi Kalimantan Timur (Studi Kasus Kewenangan Pengelolaan Kehutanan, Pertambangan dan Perkebunan). Jurnal Borneo Administrator Vol. 8 No. 1.

Nadir, Sakinah. (2013). Otonomi Daerah dan Desentralisasi Desa: Menuju Pemberdayaan Masyarakat Desa. Jurnal PolitikProfetik Vol. 1, No. 1.

Nurasa, T. Setiajie, I. (2008). Dampak Kebijakan Perdagangan Gula terhadap Profitabilitas Usahatani Tebu: Kasus di Kabupaten Klaten, Jawa Tengah. Jurnal Perdagangan Vol. 11, No. 2.

Salfadri. Tanpa Tahun. Faktor-Faktor yang Mempengaruhi Perdagangan Antar Daerah komoditas Ayam Potong di Provinsi Sumatra Barat. Jurnal Penelitian Sosial dan Ekonomi.

Sarwono. (2014). Analisis Daya Saing Kedelai Indonesia. Jurnal Ekonomi dan Bisnis.

Satryana, M. Karmini, N. (2016). Analisis Daya Saing Ekspor The Indonesia ke Pasar ASEAN Periode 2004-2013. Jurnal Ekonomi Pembangunan Unud.

Setiawan, M. (2014). Analisis Sektor Ekonomi Basis dalam Mendorong Pertumbuhan Ekonomi Kota Batu. Jurnal Ilmiah.

Setiawan. Hartono dan Suryanti. (2014). Analisis Daya Saing Komoditas Kelapa di Kabupaten Kupang. 